УДК 821.111-3.09 Барнс

Мохначева О. В., кандидат филолологических наук, доцент кафедры русской филологии и зарубежной литературы ГВУз «Криворожский государственный педагогический университет»

\title{
ТОЖДЕСТВО ГЕРОЯ В УСЛОВИЯХ ЖАНРОВОГО ЭКСПЕРИМЕНТА СОВРЕМЕННОГО РОМАНА («Предчувствие конца» Дж. Барнса)
}

У статті розглянуто один з аспектів жанрової стратегї роману на сучасному етапі його розвитку - статус героя як иентроутворюючого фактору в грі з художньою формою та структурами тексту. На конкретному прикладі простежено трагедія ідентичності «я», а також проблема тотожності героя часовому континууму.

Ключові слова: роман, жанровий експеримент, тотожність героя.

The article considers one of the aspects of the genre strategy of the novel at the present stage of its development - the status of the character as a center-forming factor in the interplay with the artistic form and text structures. Basing on a particular example, the tragedy of the "I" identity has been traced, as well as the problem of the corresponding the character'sidentity to temporal continuum.

Keywords: the novel, genre experiment, hero's identity.

В статье рассмотрен один из аспектов жанровой стратегии романа на современном этапе его развития - статус героя как иентрообразующего факторав игре $c$ художественной формой и структурами текста. На конкретном примере прослежена трагедия идентичности «я», а также проблема тождественности героя временному континууму.

Ключевые слова: роман, жанровый эксперимент, тождество героя. 
Статус романа как ведущего жанра современности определился в литературной научной мысли еще в начале XX столетия, когда были обозначены принципы романного способа постижения бытийных смыслов и их отражения. Вопрос о специфике романного жанрообразования приобрел с тех пор широкую разработку как в отечественном, так и в зарубежном литературоведении. Особенную известность приобрели теория полифонического романа М. Бахтина, исследование генезиса романа В. Кожинова, анализ эпического аспекта поэтики романа Е. Мелетинского, наблюдения Н. Рымаря, Н. Тамарченко, Г. Косикова, подходы к изучению постмодернистских вариантов жанра в работах В. Пестерева и пр. Западная теория романа ориентирована на книги Р. Уильямса «Реализм и современный роман», «Подъем романа» Я. Уотта, исследования М. Брэдбери и Д. Лоджа, И. Хассана, Ф. Моретти, Р. Барта, У. Эко и мн. др.

Многообразие аспектов изучения романа, в том числе и сточки зрения его жанровых особенностей, актуально и оставляет открытыми для исследования такие зоны, как проблема «глубинных диалогических связей человека и мира» [Рымарь 2000:89] - вопрос о тождестве героя тому вызову, который определяется жанровым заданием текста.

Цель данной статьи: исследовать соответствие конструкции романного текста художественному приему тождества героя в современном тексте, в частности в романе «Предчувствие конца» Дж. Барнса.

Парадигма «герой-художественная реальность-текст» - одна из важнейших в жанровой системе романа и связана с проблемой романного времени. Соотнесенное с теорией относительности Эйнштейна, обоснование хронотопа как жанрообразующего центра текстадало возможность М. Бахтину утверждать, что «хронотоп как формально-содержательная категория определяет (в значительной мере) и образ человека в литературе» [Бахтин 1975:121]. То есть, условия времени и места событий человеческой деятельности, судьбы и решений являются предметом изображения в произведении не сами по себе, но составляют обоснование «человеческого 
тождества» героя в процессе разного рода испытания (например, испытания на призванность, избранничество, гениальность, приспособленность к жизни и пр.). По мысли М. Бахтина, это есть организационная идея романа вплоть до XX в., когда проблема взаимоотношений героя и художественного пространства обостряется под влиянием модернистских теорий о дегероизации текста.

В 30-е годы XX века испанский философ X. Ортега-и-Гассет в знаменитой работе «Дегуманизация искусства» предсказывал тенденцию к разделению общества на ранги «заурядных и вылающзихся» людей, по-разному ориентирующихся в культурном поле, ипризвал в процессе создания нового искусства «оторваться от реальности», так как она, «рассматриваемая с разных точек зрения, расщееляется на множество отличных друг от друга реальностей» [Ортега-и-Гассет 1991:4]. Сумбур в восприятии и «озабоченность собственно человеческим» делают недоступным для большинства то эстетическое переживание, которое и есть цель искусства, считает Ортега-и-Гассет. Отделяя произведение от реальности, философ в том числе включает в систему разрушения привычных ориентиров и роман: исчерпанность жанровой формы романа обусловлена здесь «значительныл недостатком сюжетов» и его «провинциальностью», т.е. созданием иного вымышленного пространства, противостоящего подлинному миру и не выдерживающего конкуренции с ним («Мысли о романе»). Опасения о гибели романа основаны не только на исчерпанности «жанрового месторождения», как автор называет процесс романо-творчества, но и на разрушении связи «формасодержание» как центрального понятия в теоретическом аспекте вопроса о критериях жанрообразования, на вымывании человеческого аспекта из текста, сосредоточенного на изобретении сюжета.

На этом этапе сомнений в жизнеспособности романа развитие литературных технологий привело к поиску стратегий, которые проявились в нем во всем разнообразии. В. Пестерев указывает на ключевые из них: «Синтетичность, полистилистика, жанровая полифония, многоуровневые 
пространства языка и текста, интертекстуальность, саморефлексия, метаповествование, внежанровые и внелитературные формы, условность $u$ романный мимесис, метаморфозы авторского «я» $и$ читателя, игра означающего с означаемым, линейные $и$ нелинейные структурысоставляющие современного романного контекста» [Пестерев 2011:155]. Сохранив свое значение в системе литературной иерархии, роман XXI столетия нашел многие структурные ходы, изобрел различные писательские техники, при этом не пренебрегая вниманием к проблеме героя и его адаптации к той сложной системе текста, изобретению которой зачастую подчинено жанровое художественное задание.

Образцом такого сложного взаимоотношения между изощренной структурной конструкцией текста и проявлением позиции героя, его тождественности ситуации может служить роман Барнса «Предчувствие конца».

Джулиан Барнс (р. 1946) - один из самых известных английских писателей эпохи постмодерна, получивший широкую известность романом «История мира в 10 с половиной главах» (1989) и трижды проходивший в шортлист Букеровской премии - «Попугай Флобера» (1984), «Англия, Англия» (1998), «Артур и Джордж» (2005). В 2011 году роман «Предчувствие конца» принес Барнсу победу: Букеровская премия была вручена ему за «смысловую насыщенность и информативность романа», жюри премии отметило также и игру с жанрами как одну из наиболее характерных черт творчества писателя. «Иронизируя в своей речи над противопоставлением «читабельных» $u$ «качественных» книг, глава жюри Стелла Римингтон согласилась отнести «Предчувствие концая» к первой категории, но отметила, что, по ее мнению, редкому читателю удастся проникнуть в мир этого романа с первого же прочтения〉 [Ершова 2011]. Отмеченное здесь сложное соотношение адреса текста и разных уровней читательского восприятия («заурядного» ранга и «выдающегося») предполагает особенности построения структуры романа, а также условность позиции повествователя: опрокидывание свидетельства 
главного героя о давних событиях, которые положены в сюжетную основу текста.

«Предчувствие конца» хорошо иллюстрирует всю палитру постмодернистских стратегий в построении романной структуры современного типа, несмотря на то, что в сравнении с предыдущими романами, ставшими иконами постмодернизма, эта книга была оценена жюри скорее как «изысканное, умное, структурированное произведение, отвечающуее духу английской классической литературы» [Ершова 2011]. Построенный из воспоминаний и рефлексии героя, роман состоит из двух частей, и это история, которую Дж. Барнс предвосхитил определенной установкой: «Я хотел написать книгу о времени и памяти, о том, что время делает с памятью. Также о том, что память делает со временем. И о том, что в определенный момент вы понимаете, что оиибались в чем-то главном» [Барнс 2017:1]. Коллаж как структурный прием особенно заметно работает в первой части книги: мотивы, кусочки реальности, предметные образы сливаются в воспоминаниях «льсого дядьки за местьдесят» Тони Вебстера о школьных годах, его дружбе с тремя сверстниками, мучительном любовном опыте. Тони Уэбстер не простой герой, он напряженно осмысливает события, которые восстанавливает в памяти, соотносит себя и время: «Bсе мbl существуем во времени - оно нас и формирует, и калибрует, но у меня такое ощущение, что я его никогда до концуа не понимал〉 [Барнс 2017:2]. Высказанное понимание роли времени в процессе «калибровки» личности цементирует сюжетные ходы романа и соотносится с особенностями его повествовательной структуры. Характерное для классического романа линейное изложение событий, размышление над ними и попытки философского осмысления, а также элементы ретроспекции и дневниковые записи синтезированы в тексте с фрагментами эссе. В процессе восстановительной работы памяти выявляются нестыковки, неверные оценки и подложные воспоминания, которые проявляются во второй части романа и в некотором роде становятся откровением для самого героя. Сюжетно и композиционно роман все туже 
закручивается на проблеме самоидентификации Тони Уэбстера, его сознание это фокус текста, на первый план выходит проблема тождества героя его опыту - художественной реальности романа.

Лейтмотив романа - время и его многочисленные парадоксы («Говорят, время настигает каждого» [Барнс 2017:72]; «Пора бы нам усвоить, что время работает не как фиксаж, а скорее как растворитель» [Барнс 2017:60]; «Но время... Сначала оно преподает нам урок, а после скручивает в бараний рог» [Барнс 2017:88]) и его роль в постижении жизненного опыта, переосмыслении прожитого, в эволюции личности («разница между молодостью и старостью заключается, среди прочего, в том, что молодые придумывают для себя будущеее, а старики - прошлое» [Барнс 2017:50]). Время отформатировало человеческую суть Тони, проявило его роль в судьбе связанных с ним людей, особенно, Вероники и Адриана. Он сам называет себя «бесконфликтным», по оценке Вероники - он «трус», друзья считают его человеком пассивным, бывшая жена «видит его насквозь». И только в документе из прошлого, в письме Адриану, перечитанному через 40 лет после его самоубийства, Тони реализуется как «злобныци ревнивыц хам», что дает основания переоценить все, что он помнил и рассказывал: «А когда я писал, что время все расставит по местам, я кое-что недооченил, вернее, просчитался: время поставило на место одного меня» [Барнс 2017:94]. Сюжетная игра с «приметами человеческого тождества» (М. Бахтин) - мотивами встречи - утраты - поисков - обретения - в данном случае оборачивается для героя потрясением, непривычными угрызениями совести и открытием всебе«чувства более сложного, запутанного, первобытного».

Вторая сквозная тема романа - это философия самоубийства, как физического, так и духовного, интеллектуального, что на разных временных этапах истории Тони Уэбстера по-разному «отзеркаливает» процесс самопознания героя, становится для него своего рода испытанием на неизменность, на самотождественность, которого он не выдерживает. Главная тема романа - память, еe причуды, еe парадоксы, спасительная сила и 
безжалостное несовершенство. Прожив жизнь, в которой он не знал сомнений, Тони Уэбстер в предчувствии ее конца постигает, что«нужно допускать, хотя бы в теории, что наша память существует не просто так, а во времени. Мы движемся сквозь годы, описывая те же самые петли, возврашаясь к одним и тем же событиям и чувствам» [Барнс 2017:87].

С точки зрения жанрового движения текста смыслом романа оказывается не сложный, оригинальный сюжет, а как раз нетождественность героя тому, что он рассказывает: Тони плохо анализирует свои поступки, он неверно оценивает происходящее, утрачивает и доверие как рассказчик, и сочувствие как герой истории, не сохраняет даже тождество самому себе - не наделенный героическим пафосом, он в течении своей жизни не совпадал со временем, выпал из него и по прошествии многих лет испытал потрясение, осознав смысл своих «тогдашних» поступков. Конфликт выдающихся и заурядных людей, согласно Ортега-и-Гассету, проник в ткань романа, обобщив в нем индивидуальную судьбу через многократно повторенную в тексте догадку: «История - это уверенность, которая рождается на том этапе, когда несовершенства памяти накладываются на нехватку документальных свидетельств» [Барнс 2017:47]. Документы, полученные героем в финале, лишают его правоты в оценке его личной истории, но делают его тождественным заданию романа, заложенной в нем полемике, подчиняют концепции всего творческого замысла Барнса. В эпоху литературных величинметафор (Коллекционеров, Парфюмеров, Чтецов) герой Барнса - это еще и возврат к поискам человеческого тождества личности.

\section{БИБЛИОГРАФИЯ}

Рымарь 2000 - Рымарь Н. Т. Романное мышление и культура XX века // Литературный текст : проблемы и методы исследования. Аспекты теоретической поэтики : К 60-тилетию Н. Д. Тамарченко - Вып. 6 / Н. Т. Рымарь. - М.; Тверь, 2000. - С. 88-102. 
Бахтин 1975 - Бахтин М. М. Формы времени и хронотопа в романе. Очерки по исторической поэтике // Бахтин М. М. Вопросы литературы и эстетики. - М. : Худож. лит., 1975. - С. 234-407.

Ортега-и-Гассет 1991 - Ортега-и-Гассет Х. Эстетика, философия культуры : [Вступ. ст. Г. М. Фридлендера ; Сост. В. Е. Багно] / Х. Ортега-иГассет. - М. : Искусство, 1991. - 588 с.

Пестерев 2011 - Пестерев В. А. Романная проза запада рубежа XX и XXI веков // Вестник Пермского университета. Российская и зарубежная филология / В. А. Пестерев. - Пермь, 2011. - Вып. 3(15). - С. 155-166.

Ершова 2011 - Ершова Т. Двойная победа: Джулиан Барнс стал лауреатом Букеровской премии [Электронный ресурс] / T. Ершова. - Режим доступа : https://lenta.ru/articles/2011/10/19/barnes/

Барнс 2017 - Барнс Дж. Предчувствие конца [Перев., прим. Е. Петрова] / Дж. Барнс. - М. : Азбука-Аттикус, 2017. - 160 с. 